\title{
Why was Gaceta Médica de México founded?
}

\author{
Martha Eugenia Rodríguez-Pérez \\ Academia Nacional de Medicina, Gaceta Médica de México, Ciudad de México, México
}

Currently, in Mexico there are countless periodical publications specialized in medicine, propitious and timely, as Dr. Gonzalo Castañeda would say "to briefly and promptly communicate yesterday's acquisition..., the idea that has just emerged from the mind of the thinker", but the oldest one is Gaceta Médica de México, dating from September 15, 1864. It was published by members of the Scientific, Literary and Artistic Commission of Mexico Medical Sciences Section, created in 1864 at the instance of members of the French expeditionary army.

The association, created on April 30, 1864 and initially named Medical Sciences Section, was transformed in 1865 into the Medical Society of Mexico and in 1873 into the National Academy of Medicine, with Gaceta Médica de México being preserved as its official publication. The Medical Sciences Section was integrated by 22 health specialists, 10 Mexicans and 10 French, one German and one Italian. Its chairman was Dr. Carlos Alberto Ehrmann and the vice chairmen, first and second, respectively, Miguel Francisco Jiménez and Julio Clement, who, in collaboration with the other members, noticed the need to preserve the works presented in the association. The best way to disseminate them was precisely through journalism.

After four months of gathering the material presented in the Wednesday sessions, the first Gaceta Médica de México number was published. Its initial document entitled "Prospectus" (Gac Med Mex. 1864; 1 (I): 1), reads: "The favorable reception that has constantly been given in our country to the repeated efforts thus far to popularize sciences, and especially Medicine, by means of periodicals, has sufficiently proven the need for such publications." Doctors Ehrmann and Jiménez, the authors, showed that the Academy required a journal due to the work that was being carrying out, for "the activity that is seen among its members... the regularity of their works and... the enthusiasm that originates the amenity of their meetings", which exceeded the established schedule.

To facilitate subscriptions to the journal, two spaces were appointed: Don Antonio de la Torre's cupboard (which currently would be equivalent to a newspaper stand) and the publisher's personal address, i.e., doctor Luis Hidalgo y Carpio, specialist in legal medicine and author of the medical doctrine contained in the Mexican Penal Code, which would be promulgated by president Benito Juárez in 1871.

Gaceta "seized" knowledge, since in its pages it included information from foreign publications, in addition to "as many communications of interest intelligent people want to submit." It was hoped for the spirit of fellowship to be boosted, "which everywhere distinguishes the most selected portion of doctors." The journal would reflect the scientific-ideological movement of health areas; it would be governed by same freedom that characterized academic discussions and each author would be accountable for the concepts he expressed. In order for readers to reach full comprehension, a bilingual publication was thought of, which was fulfilled only in the first volume, which included articles in Spanish and French; for the following volumes, the team of translators was called upon.

The Academy of Medicine members attended the sessions to exchange knowledge about national epidemiology, to know the etiology of diseases that reigned in Mexico and to seek solutions. These concerns were expressed in Gaceta, where the Mexican medical community left in writing the discussions and works presented in the Academy.

Hidalgo y Carpio and the editors that followed, including Agustín Andrade, José María Reyes and Domingo Orvañanos, pointed out that they wanted Gaceta Médica de México to be known in the "scientific world", hence their interest to cross the Mexican borders through the exchange of publications. In 1886 ,
Correspondence:

Martha Eugenia Rodríguez-Pérez

E-mail: martha.eugenia.rp@gmail.com
Date of reception: 02-07-2018

Date of acceptance: 10-07-2018

DOI://dx.doi.org/10.24875/GMM.M18000167
Gac Med Mex. 2018;154:355-356

Contents available at PubMed www.gacetamedicademexico.com 
the print run was 350 copies, which were distributed to members, 35 national scientific societies and 75 foreign societies. To achieve a good administration, the editor received a salary of 480 pesos annually.

The topics that were addressed in the various volumes of the $19^{\text {th }}$ century Gaceta include medical discoveries and new theories (such as the cell theory), surgical, anesthesia, antisepsis and asepsis advances, whereby surgery became very attractive; the birth of bacteriology, the discussion on the smallpox vaccine, the incorporation of technology to medicine, the emergence of medical specialties in Mexico as of 1888 (ophthalmology, gynecology, bacteriology and mental diseases) and recurrent diseases.

In 1877, Gaceta announced that typhus was alarming the population because it was stationed in the capital and was spreading throughout the national territory. Years later, in 1915, among other media, Gaceta Médica de México disseminated the statements of Dr. José María Rodríguez, chairman of the Higher Council of Health, regarding the identification of the louse as vector of disease transmission.

It was such an abundance of material and topics that were sheltered by Gaceta that, in 1886, Agustín Andrade, founding member of the Academy, expressed the need to develop an index of the publication. After arduous work, in 1888, the Gaceta editor, Dr. Manuel S. Soriano, announced the publication of the general index of the Gaceta Médica 23 volumes, by subjects and authors; its price: two pesos. The catalog was so useful and novel at the time, that it was exhibited at the stand that Mexico installed in the 1889 World's Fair in Paris, precisely when the construction of the Eiffel Tower was completed, which would serve as the celebration main symbol.
Dr. Francisco Fernández del Castillo prepared the Gaceta Médica de México index that covers from 1836 to 1956, since it includes the first Academies' publications: Periódico de la Academia de Medicina de Mégico, six volumes, published between 1836 and 1843, and Periódico de la Academia de Medicina de Mégico, one volume, and Unión Médica de México, two volumes, 1856 to 1858 . The list that covered the period from 1957 to 1976 was carried out by Alejandro Somolinos. Needless to mention the benefits of the catalog, which allows an easy handling of the journal, and its updating is therefore pending.

When the year 1900 arrived and Gaceta volume 37 was being published, the Publications Commission resolved to finish the first era, and, for the new century and year, to begin a second series, as required by typographical advances, and thus the following numbers improved the presentation, which was to be in coated paper.

In short, Gaceta Médica de México, always crafted with great professionalism, is the National Academy of Medicine official journal, the purpose of which is to transmit research carried out in matters of health, the discussion, analysis and reflection on the postulates of science, as well as the means of dissemination of posture documents, and we could therefore say that the phrase of the chairman of the Academy in 1866, Dr. Miguel Francisco Jiménez, is still valid:

... our only purpose [by publishing Gaceta] is to leave, collected, without confounding, the events we have been witness of, so that in more serene days and by more competent men, they can be fertilized with a positive advantage and utility for science. they will, certainly, bear testimony on the originality of the addressed subjects, the love for study and the national interest that encourages us...

(Jiménez MF. Closing session, Gac Med Mex. 1866;2: 385-386). 